\title{
Nutritivna vrijednost suhih šunki i pršuta
}

Đuro Senčić ${ }^{1}$ Danijela Samac ${ }^{1}$

\begin{abstract}
SAŽETAK
Zbog visokog sadržaja kuhinjske soli i kolesterola te sastojaka dima, suhomesnati proizvodi su smatrani lošim namirnicama za ljudsko zdravlje jer doprinose aterosklerozi i hipertenziji. Međutim, suhe šunke i pršuti su namirnice animalnog porijekla u prehrani ljudi, bogate s hranjivim tvarima. Značajan su izvor bjelančevina i masti, koje su u djelomično razgrađenom obliku djelovanjem endogenih enzima proteaza i lipaza. Posebice su bogati izvor slobodnih aminokiselina (esencijalnih i neesencijalnih) i masnih kiselina. Sastav slobodnih aminokiselina ovisi o genotipu svinja (enzimatski sastav mišića), tehnologiji prerade $i$ dužini zrenja suhih šunki i pršuta. Sastav slobodnih masnih kiselina najviše ovisi o hranidbi svinja (sastav hrane), sustavu držanja svinja (otvoreni, zatvoreni), ali i o genotipu svinja. Omjer između polinezasićenih (PUFA) i zasićenih (SFA) masnih kiselina najčešce je ispod preporučenih vrijednosti (0,4-1), a omjer između ukupnih n-6 i n-3 masnih kiselina je iznad preporučenih vrijednosti WHO (2003.). Zbog visokog sadržaja kuhinjske soli (natrija), treba biti oprezan u prehrani sa suhom šunkom i pršutom kod ljudi koji boluju od kardiovaskularnih bolesti i hipertenzije. Suhe šunke i pršuti su dobar izvor mineralnih tvari, naročito cinka, željeza i selena kao i vitamina, osobito onih iz skupine B. Zbog visokog sadržaja hranjivih tvari u lako probavljivom $i$ slobodnom obliku, suhe šunke i pršuti su naročito pogodni u prehrani sportaša.

Ključne riječi: suhe šunke, pršuti, nutritivna vrijednost
\end{abstract}

\section{UVOD}

Suhe šunke (njem. Schinken - šunka, pršut) su trajni suhomesnati proizvodi nastali umjetnim sušenjem (dimljenje) svinjskih butova u krajevima s vlažnom i hladnijom klimom (npr. slavonska šunka). Pršuti (tal. prosciutto - osušiti, ocjediti) su trajni suhomesnati proizvodi nastali sušenjem svinjskih butova prirodnim putem (provjetravanje), npr. Istarski pršut, ili kombiniranom primjenom umjetnog sušenja (dimljenje) i prirodnog sušenja (npr. Dalmatinski pršut) u cilju njihova očuvanja (konzerviranja) kroz duže vrijeme. U prošlosti su se suha šunka ili pršut, zbog skupoće, rjeđe koristili u prehrani, uglavnom za crkvene blagdane (Uskrs, imendani i dr.) i za vrijeme težih i obimnijih poljoprivrednih poslova (žetva, vršidba, berba vinograda i dr.). S porastom standarda stanovništva, ove namirnice su u češćoj upotrebi tijekom cijele godine. Zbog visokog sadržaja kuhinjske soli i kolesterola te sastojaka dima, smatrane su lošima za ljudsko zdravlje jer doprinose aterosklerozi i hipertenziji. Je li baš tako, i kakva je prava nutritivna vrijednost suhih šunki i pršuta, ukazuje se u ovome članku.

\section{Osnovni kemijski sastav suhih šunki i pršuta}

Osnovni kemijski sastav suhih šunki odnosno pršuta, vidljiv je iz tablice 1. Sadržaj vode (vlage) u suhoj šunki ili pršutu može varirati, zavisno o vrsti proizvoda, njihovoj težini, tehnologiji prerade (dužina sušenja i zrenja, način primarne obrade i dr.) i sadržaju potkožne i intramuskularne masti. Tako, npr., veći stupanj dehidracije Istarskoga pršuta posljedica je skidanja kože i potkožnoga masnoga tkiva pri obradi buta.

\footnotetext{
1 Prof. dr. sc. Đuro Senčić, doc. dr. sc. Danijela Samac - Sveučilište J. J. Strossmayera u Osijeku, Poljoprivredni fakultet u Osijeku, Zavod za stočarstvo, Vladimira Preloga 1, 31000 Osijek
} 
Tablica 1. Usporedni prikaz osnovnog kemijskog sastava Slavonske šunke te Istarskog i Dalmatinskog pršuta

\begin{tabular}{|c|c|c|c|} 
Hranjive tvari & $\begin{array}{c}\text { Slavonska } \\
\text { šunka } \\
\text { (Senčić i sur., } \\
\text { 2015.) }\end{array}$ & $\begin{array}{c}\text { Istarski pršut } \\
\text { (Karolyi, } \\
\text { 2006.) }\end{array}$ & $\begin{array}{c}\text { Dalmatinski } \\
\text { pršut } \\
\text { (Kos, 2011.) }\end{array}$ \\
\hline Voda, \% & $52,30 \pm 2,50$ & $39,99 \pm 1,94$ & 44,07 \\
\hline Bjelančevine, \% & $27,50 \pm 2,20$ & $40,73 \pm 3,55$ & 29,35 \\
\hline Mast, \% & $10,00 \pm 2,25$ & $16,91 \pm 4,59$ & 18,36 \\
\hline NaCl, \% & $5,95 \pm 1,50$ & $6,45 \pm 0,81$ & 7,09 \\
\hline Pepeo, \% & $8,00 \pm 2,00$ & $8,37 \pm 0,79$ & 8,00 \\
\hline
\end{tabular}

Suhe šunke i pršuti su, ponajprije, bogati izvor bjelančevina. Udio bjelančevina varira, ovisno o sadržaju intramuskularne masti i vode, a što je pod utjecajem genotipa svinja, tjelesnoj masi svinja prije klanja, odnosno sastavu svježih butova i dužini sušenja i zrenja. Najveći udio bjelančevina $(40,73 \%)$ ima Istarski pršut, a najmanji (27,50 \%) slavonska šunka.

Udio masti u suhoj šunki ili pršutu može varirati, ovisno o genotipu svinja i načinu njihove hranidbe. Tako Istarski pršut ima visok sadržaj masti, zbog manjeg udjela vode. Suhe šunke odnosno pršuti od svinja masnih i polumasnih genotipova imaju više masti (veći sadržaj intermuskularnoga masnoga tkiva) od istovjetnih proizvoda svinja mesnatih genotipova.

Sadržaj natrijevoga klorida $(\mathrm{NaCl})$ je za potrošače jedan od važnijih parametara kvalitete suhih šunki i pršuta. Smatra se da sadržaj kuhinjske soli u zreloj suhoj šunki treba biti manji od $6 \%$. U proizvodnji Parmskoga pršuta, npr., standardizirana je slanost na 5-6\%. Prevelika količina soli u tim proizvodima inhibira proteolizu, nepovoljno utječe na njihov okus i podstiće hipertenziju u potrošača. Svjetska zdravstvena organizacija (WHO; World Health Organization) preporuča dnevni unos kuhinjske soli do $2000 \mathrm{mg}$.

\section{Aminokiselinski sastav suhih šunki i pršuta}

Suhomesnati proizvodi (suhe šunke i pršuti) predstavljaju visoko koncentrirani izvor biološki vrijednih bjelančevina i slobodnih aminokiselina. Slobodne aminokiseline nastaju procesom proteolize, tijekom zrenja šunki i pršuta, pa je njihova koncentracija proporcionalna vremenu zrenja. Slobodne aminokiseline lakše se, prilikom konzumacije suhih šunki, resorbiraju u organizam, jer su bjelančevine djelomično već razgrađene. Svaki od navedenih proizvoda ima karakterističan aminokiselinski profil. $U$ tablici 2. prikazan je aminokiselinski sastav nekih suhih šunki i pršuta u g na 100 g uzorka.

Iz tablice 2. vidljivo je da je u Istarskome pršutu najzastupljenija neesencijalna glutaminska kiselina $(0,711 \mathrm{~g})$, a zatim esencijalna aminokiselina lizin $(0,597$ g). U Iberijskoj šunki najzastupljenija je ami-
Tablica 2. Aminokiselinski sastav Istarskog pršuta i Iberijske šunke (g/100 g)

\begin{tabular}{|c|c|c|}
\hline Aminokiseline & $\begin{array}{c}\text { Istarski pršut } \\
\text { (Karolyi, 2006.) }\end{array}$ & $\begin{array}{c}\text { Iberijska šunka } \\
\text { (Garzia-Gonzales i } \\
\text { sur., 2013.) }\end{array}$ \\
\hline Alanin & 0,408 & - \\
\hline Arginin & 0,271 & 0,301 \\
\hline Asparaginska kiselina & 0,313 & 0,195 \\
\hline Cistein & 0,036 & - \\
\hline Glutaminska kiselina & 0,711 & 0,739 \\
\hline Glicin & 0,251 & 0,119 \\
\hline Histidin & 0,184 & 0,226 \\
\hline Izoleucin & 0,224 & 0,391 \\
\hline Leucin & 0,387 & 0,353 \\
\hline Lizin & 0,597 & 0,966 \\
\hline Metionin & 0,162 & 0,209 \\
\hline Fenilalanin & 0,226 & 0,286 \\
\hline Serin & 0,233 & 0,255 \\
\hline Treonin & 0,218 & - \\
\hline Triptofan & - & 0,210 \\
\hline Prolin & 0,282 & 0,197 \\
\hline Tirozin & 0,164 & 0,150 \\
\hline Valin & 0,270 & 0,402 \\
\hline & & \\
\hline
\end{tabular}

nokiselina lizin $(0,966 \mathrm{~g})$, a zatim neesencijalna glutaminska kiselina $(0,739 \mathrm{~g})$.

Razlike u sadržaju slobodnih aminokiselina u suhim šunkama i pršutima mogu se pripisati različitoj proteolitičkoj aktivnosti između genotipova svinja (Rosell i Toldra, 1998.; Hernandez i sur., 2004.), spolova (Armeri i sur., 1999.), dobi svinja (Toldra i sur., 1996.), stresnoj osjetljivosti svinja (Claeyes i sur., 2011.), sadržaju soli (Schivazappa i sur., 2002.; Virgili i sur., 1999.) i pH vrijednosti (Schivazappa i sur., 2002.; Toldra, 2006.; Martin i sur., 2001.). Schivazappa i sur. (2002.) te Toldra (2006.) su naveli da je veća proteolitička aktivnost enzima u pršutima s nižom pH vrijednosti.

Virgili i sur. (1999.) i Schivazappa i sur. (2002.) su objavili da je veća tvorba slobodnih aminokiselina kod pršuta s manjim sadržajem soli. Martin i sur. (2001.), pak, opovrgavali su navode prethodnih autora i tvrdili da je veća tvorba slobodnih aminokiselina kod slanijih pršuta.

Virgili i sur. (1999.) utvrdili su da najveću količinu slobodnih aminokiselina u $100 \mathrm{~g}$ uzorka ima Iberijski pršut $(8,15 \mathrm{~g})$, a zatim Korzikanski pršut $(5,85$ g), Serrano pršut (5,76 g), Parma pršut $(4,18$ g) i Bayonne pršut $(3,90 \mathrm{~g})$.

U svom istraživanju Martin i sur. (2001.) su utvrdili da je od pet najčešćih aminokiselina u pršutu najzastupljenija bila glutaminska kiselina, a zatim alanin, lizin, leucin i arginin. Vrlo sličan sastav aminokiselina utvrdili su Virgili i sur. (1999.) kod šest različitih tipova pršuta. Najzastupljenija je bila glutaminska 
kiselina $(12,0-12,5 \%)$, a zatim lizin $(10,30-13,30 \%)$ i alanin $(7,8-9,5 \%)$.

Strata (1993.) je utvrdio da je sadržaj slobodnih aminokiselina u m. biceps femoris Parmskoga pršuta bio 3,13 g/100 g uzorka nakon 12 mjeseci prerade. U istraživanju Karolyija i sur. (2002.) ukupni sadržaj slobodnih aminokiselina, zajedno s amonijakom, u Istarskome pršutu prosječno je iznosio 6,26 g/100 g uzorka nakon 18 mjeseci. Vjerojatno je viši sadržaj slobodnih aminokiselina u tome istraživanju posljedica dužeg procesa zrenja pršuta.

Posljedica proteolize je slabljenje miofibrilarne mreže, mekša konzistencija proizvoda i stvaranje spojeva koji doprinose stvaranju okusa i, općenito, boljih senzornih svojstava suhih šunki i pršuta. Osim što značajno utječu na stvaranje okusa, aminokiseline su supstrat za stvaranje Maillardove reakcije sa šećerima i Streckerove degradacije, pri čemu nastaju hlapivi aromatski spojevi (Toldra i Elores, 1998.).

\section{Masnokiselinski sastav suhih šunki i pršuta}

Slobodne masne kiseline nastaju procesom lipolize, kada se razgrađuju triacilgliceridi djelovanjem lipaza i fosfolipidi djelovanjem fosfolipaza. Relativni udio slobodnih masnih kiselina ovisi o početnom sastavu triacilglicerida i fosfolipida (Toldra, 2006.). Sastav masnih kiselina suhih šunki i pršuta ovisi nājviše o sastavu masti iz hrane, a djelomično i o genotipu svinja. U svježem mesu sadržaj slobodnih masnih kiselina je 1-2 \%, a kod zrelih šunki i pršuta 10-12 $\%$ u odnosu na ukupan sadržaj masti. Na aktivnost lipolitičkih enzima utječu pH vrijednosti, sadržaj soli, aktivnost vode, temperatura i brzina sušenja. Slobodne masne kiseline, posebice nezasićene, sklone su oksidaciji, pri čemu nastaju različiti hlapivi spojevi (alkoholi, aldehidi, ketoni i dr.) koji utječu na poželjan miris suhih šunki ili pršuta. Prevelika lipidna oksidacija nezasićenih masnih kiselina može uzrokovati ranketljivi miris i žutu boju masti. Masnokiselinski sastav nekih vrsta trajnih suhomesnatih proizvoda, dat je u tablici 3.

Kao što je iz tablice 3. vidljivo, najzastupljenije masne kiseline u Iberijskoj šunki i Istarskom i Dalmatinskom pršutu pripadaju skupini mononezasićenih masnih kiselina (MUFA; Monounsaturated fatty acids), zatim skupini zasićenih masnih kiselina (SFA; Saturated fatty acids), a najmanje skupini polinezasićenih masnih kiselina (PUFA; Polyunsaturated fatty acids). U skupini MUFA najzastupljenija je oleinska kiselina (C 18: 1 n-9), u skupini SFA glavne masne kiseline su palmitinska (C $16: 0$ ) i stearinska (C 18:0), a u skupini PUFA to je linolna kiselina (C 18 : $2 \mathrm{n}-6 \mathrm{c}$ ) i L - linolenska kiselina (C $18: 3 \mathrm{n}-3$ ).
Tablica 3. Usporedni prikaz masnokiselinskog sastava Iberijske šunke i pršuta

\begin{tabular}{|c|c|c|c|}
\hline Masne kiseline & $\begin{array}{l}\text { Istarski } \\
\text { pršut } \\
\text { (Pleadin i } \\
\text { sur., 2015.) }\end{array}$ & $\begin{array}{c}\text { Iberijska } \\
\text { šunka } \\
\text { (Jurado } \\
\text { i sur., } \\
2008 . \text {.) }\end{array}$ & $\begin{array}{l}\text { Dalmatinski } \\
\text { pršut } \\
\text { (Kos, 2011.) }\end{array}$ \\
\hline C 10: 0 Kaprinska & $10 \pm 0,02$ & - & - \\
\hline C 12: 0 Laurinska & $0,10 \pm 0,04$ & - & - \\
\hline C 14: 0 Miristinska & $1,42 \pm 0,26$ & 1,27 & $1,37 \pm 0,03$ \\
\hline C 16: 0 Palmitinska & $25,95 \pm 1,98$ & 22,92 & $24,99 \pm 0,26$ \\
\hline C 17: 0 Heptadekanska & $0,29 \pm 0$ & - & $0,18 \pm 0,02$ \\
\hline C 18: 0 Stearinska & $13,51 \pm 1,71$ & 7,45 & $14,00 \pm 0,24$ \\
\hline C 20:0 Arahidska & $0,24 \pm 0,08$ & - & $0,25 \pm 0,01$ \\
\hline C 16:1 Palmitoleinska & $2,85 \pm 0,67$ & 3,39 & $2,95 \pm 0,11$ \\
\hline $\begin{array}{l}\text { C } 17: 1 \mathrm{C} \\
\text { heptadek }\end{array}$ & - & - & $0,19 \pm 0,02$ \\
\hline C 18: 1 n-9t Elaidična & $0,05 \pm 0,08$ & - & - \\
\hline C $18: 1$ n-9c Oleinska & $46,92 \pm 3,58$ & 54,51 & $44,23 \pm 0,43$ \\
\hline C $20: 1$ Cis-11-eikozenska & $0,59 \pm 0,45$ & - & $0,95 \pm 0,02$ \\
\hline C $21: 0$ Heneikozano & $0,10 \pm 0,16$ & - & - \\
\hline C 22: 1 n-9 Eručna & $0,03 \pm 0,07$ & - & - \\
\hline C $18: 2$ n-6c Linolna & $7,51 \pm 2,99$ & 9,41 & $8,47 \pm 0,43$ \\
\hline C $20: 2$ n-6c Eikozadienska & - & - & $0,47 \pm 0,03$ \\
\hline C $20: 4$ n-6 Arahidonska & - & 0,20 & $0,38 \pm 0,03$ \\
\hline C 18:3 n-3 L-linolenska & $0,57 \pm 0$ & - & $0,42 \pm 0,03$ \\
\hline C $18: 3 n-6 y$-linolenska & $0,07 \pm 0,11$ & - & - \\
\hline C $20: 3$ n-6 Eikozatrienska & - & - & $0,17 \pm 0,01$ \\
\hline C $22: 2$ Dokosadienoična & - & - & $0,55 \pm 0,12$ \\
\hline
\end{tabular}

Tijekom proizvodnje suhih šunki i pršuta dolazi do povećanja relativnog udjela MUFA te smanjenja udjela PUFA, a udio SFA je skoro nepromijenjen. Razlog toga je oksidacija nezasićenih masnih kiselina s dvostrukim vezama (Larrea i sur., 2007.).

U tablici 4. prikazan je ukupni sadržaj SFA, MUFA i PUFA te njihovi spojevi u različitim trajnim suhomesnatim proizvodima. Zbirni rezultati za navedene masne kiseline u pojedinim istraživanjima mogu biti rezultat različite hranidbe svinja (koncentrirana krmiva, žir), sustava držanja (otvoreni, zatvoreni) i genotipa svinja. Tako je, npr., Gandemer (2009.) utvrdio udio SFA, MUFA i PUFA kod Bayonne pršuta od $36,4,52,9$ i 10,7 \%, kod Parma pršuta od 36,4, 15,25 i 11,1 \%, Korzikanskog pršuta od 34,9, 55,4 i 9,7 \%, kod Serrano pršuta od 33,4, 55,6 i 11,0 \%. Božac (2010.) je naveo udio masnih kiselina kod Istarskog pršuta različitih genotipova svinja, pa je tako udio SFA bio od 35,73 do $37,19 \%$, udio MUFA od 45,53 do $47,26 \%$, a udio PUFA od 14,8 do $15,58 \%$. Preveliki udio PUFA uzrok je mekane masti i slabije oksidativne stabilnosti ove skupine trajnih suhomesnatih proizvoda. Zbog toga je udio linolne kiseline (C 18:2 n-6) u svježem butu za Parma pršute, prema zahtjevima konzorcija, ograničen na $15 \%$.

Količina i sastav masti u mesnim proizvodima koje konzumiramo, povezani su sa zdravljem ljudi i 
Tablica 4. Usporedni prikaz sadržaja i omjera zasićenih, mononezasićenih i polinezasićenih masnih kiselina u različitim trajnim suhomesnatim proizvodima

\begin{tabular}{|c|c|c|c|c|c|}
\hline Vrsta proizvoda & SFA* $(\%)$ & $\operatorname{MUFA}^{\star \star}(\%)$ & PUFA ${ }^{\star \star \star}(\%)$ & PUFA/SFA & $n-6 / n-3$ \\
\hline Slavonska šunka (Kovačević, 2017.) & $36,76-37,37$ & $51,47-51,72$ & $10,91-11,77$ & $0,29-0,32$ & $19,60-19,88$ \\
\hline Istarski pršut (Karolyi, 2006.) & 40,51 & 44,67 & 12,50 & 0,31 & 12,90 \\
\hline Dalmatinski pršut (Kos, 2011.) & $41,14 \pm 0,38$ & $48,26 \pm 0,47$ & $10,67 \pm 0,48$ & $0,22 \pm 0,01$ & $9,59 \pm 0,36$ \\
\hline
\end{tabular}

stanjem krvožilnoga sustava. Svjetska zdravstvena organizacija (WHO) preporuča smanjivanje konzumacije masti. One bi trebale osiguravati samo 10-15 $\%$ ukupnih energetskih potreba u prehrani, a svega $10 \%$ bi trebalo potjecati od zasićenih masnih kiselina. Udio PUFA u ukupnim energetskim potrebama trebao bi biti 6-10\%, od čega n-6 PUFA trebaju činiti 5-8 \%, a n-3 PUFA od 1-2 \%. Udio MUFA u energetskim potrebama ljudi treba biti 10 do $15 \%$.

Prema preporukama WHO (2003.) važan je odnos (kvocijent) između polinezasićenih i zasićenih masnih kiselina, koji bi u mesu trebao biti između 0,4 i 1, kao i odnos (kvocijent) između ukupnih n-6 i n-3 masnih kiselina, koji bi trebao biti između 1 i 4. Kao što je iz tablice 4. vidljivo, odnos PUFA/SFA kod slavonske šunke, Istarskoga i Dalmatinskoga pršuta je ispod preporučenih vrijednosti, ali je to slučaj i kod drugih pršuta (Fernandez i sur., 2007.). To je posljedica vrlo niskih vrijednosti n-3 masnih kiselina u proizvodima od svinjskog mesa $(<0,15 \mathrm{~g} / 100 \mathrm{~g})$.

Sadržaj mikro i makroelemenata te vitamina u suhim šunkama i pršutima

Sadržaj pojedinih mikronutrijenata u suhim šunkama i pršutima vidljiv je iz tablice 5 . Podaci u tablici su prilagođeni iz navoda Jimenez - Colmenero i sur. (2010.). Između pojedinih autora postoje značajne razlike u sadržaju većine minerala, a razlozi su brojni (pasmina, dob, težina, vrsta mišića i dr.). Ovi proizvodi mogu se smatrati prirodnim izvorom $\mathrm{Fe}, \mathrm{Zn}, \mathrm{P}$, $\mathrm{Se}$, tiamina, riboflavina, niacina te vitamina B6 i B12 jer sadrže značajne količine ovih hranjivih tvari, veće od $15 \%$ preporučenog dnevnog unosa (RDA - Recommended Daily/Dietary Allovance). Suhe šunke ili pršuti imaju vrlo visoku koncentraciju natrija jer sadržaj soli $(\mathrm{NaCl})$ može biti i viši od $9 \%$. Svjetska zdravstvena organizacija (World Health Organisation - WHO) preporuča maksimalni dnevni unos natrija u količini od 2000 mg (WHO, 2003.), što ograničava konzumaciju suhih šunki ili pršuta kod ljudi koji boluju od hipertenzije. Trenutni dnevni unos

Suhe šunke i pršuti sadrže značajnu količinu bioraspoloživog cinka, važnog za funkciju više od 200 enzima. Magnezij je važan u različitim metaboličkim procesima, naročito vezanim za mišićnu aktivnost.
Željezo je važno u prevenciji anemije, posebice kod djece i trudnica. Selen je važan u antioksidacijskim procesima, značajnim u prevenciji karcinoma i kardiovaskularnih bolesti. Također, sadrže značajne količine vitamina iz B-skupine, osobito B1 i B12, važnih za normalno funkcioniranje živčanog sustava. Vitamin E je u manjim količinama zastupljen u mišićnom tkivu, a više u masnom tkivu. Vitamin E smanjuje oksidaciju lipida te gubitak boje kod narezanog pršuta ili suhe šunke.

Tablica 5. Dnevni unos mineralnih tvari i vitamina konzumacijom suhe šunke ili pršuta

\begin{tabular}{|l|c|c|c|}
\hline Hranjiva tvar & $\begin{array}{c}\text { Količina u } \\
100 \mathrm{~g} \\
\text { (jiménez- } \\
\text { Colmenero i } \\
\text { sur., 2010.) }\end{array}$ & $\begin{array}{c}\text { Preporučeni } \\
\text { dnevni unos } \\
\text { (RDA) }\end{array}$ & $\begin{array}{c}\text { Udio u } \\
\text { preporučenom } \\
\text { dnevnom } \\
\text { unosu (\%) }\end{array}$ \\
\hline $\mathrm{Na}$ (Na) & $\begin{array}{c}1100-1800 \\
\mathrm{mg}\end{array}$ & - & - \\
\hline Fosfor (P) & $157-180 \mathrm{mg}$ & $700 \mathrm{mg}$ & $22-26$ \\
\hline Kalij (K) & $153-160 \mathrm{mg}$ & $2000 \mathrm{mg}$ & $7,6-8,0$ \\
\hline Kalcij (Ca) & $23-35 \mathrm{mg}$ & $800 \mathrm{mg}$ & $1,5-4,4$ \\
\hline Magnezij Mg) & $17-18 \mathrm{mg}$ & $375 \mathrm{mg}$ & $4,5-4,8$ \\
\hline Željezo (Fe) & $1,8-3,3 \mathrm{mg}$ & $14 \mathrm{mg}$ & $13-23$ \\
\hline Cink (Zn) & $2,2-3,0 \mathrm{mg}$ & $10 \mathrm{mg}$ & $22-30$ \\
\hline Selen (Se) & $29 \mu \mathrm{g}$ & $55 \mu \mathrm{mg}$ & 52 \\
\hline Tiamin (B1) & $0,57-0,84 \mathrm{mg}$ & $1,1 \mathrm{mg}$ & $51-76$ \\
\hline Piridoksin (B6) & $0,22-0,42 \mathrm{mg}$ & $1,4 \mathrm{mg}$ & $16-30$ \\
\hline Riboflavin (B2) & $0,20-0,25 \mathrm{mg}$ & $1,4 \mathrm{mg}$ & $14-18$ \\
\hline Niacin (B3) & $4,5-11,8 \mathrm{mg}$ & $16,0 \mathrm{mg}$ & $28-73$ \\
\hline Vitamin E & $0,08-1,5 \mathrm{mg}$ & $12,0 \mathrm{mg}$ & $0,7-12$ \\
\hline Vitamin B12 & $15,68 \mu \mathrm{mg}$ & $2,5 \mathrm{mg}$ & 627 \\
\hline Folna kiselina & $13,49 \mu \mathrm{gg}$ & $200 \mathrm{mg}$ & 6,7 \\
\hline
\end{tabular}

1 Preporučeni dnevni unos (Recommended Daily/Dietary Allowance), prema Direktivi 90/496/EEC (2008.) koji se ostvaruje konzumacijom $100 \mathrm{~g}$ šunke (pršuta).

\section{ZAKLJUČAK}

Suhe šunke i pršuti su namirnice animalnog porijekla u prehrani ljudi, bogate s hranjivim tvarima. Značajan su izvor bjelančevina i masti, koje su u djelomično razgrađenom obliku djelovanjem endogenih enzima proteaza i lipaza. Posebice su bogati izvor slobodnih aminokiselina (esencijalnih i neesencijalnih) i masnih kiselina. Sastav slobodnih aminokiselina ovisi o genotipu svinja (enzimatski sastav mišića), tehnologiji prerade i dužini zrenja samog proizvoda. 
Sastav slobodnih masnih kiselina najviše ovisi o hranidbi svinja (sastav hrane), sustavu držanja svinja (otvoreni, zatvoreni), ali i o genotipu svinja. Omjer između polinezasićenih i zasićenih masnih kiselina najčešće je ispod preporučenih vrijednosti $(0,4-1)$, a omjer između ukupnih n-6 i n-3 masnih kiselina je iznad preporučenih vrijednosti WHO (2003.). Zbog visokog sadržaja kuhinjske soli (natrija), ljudi koji boluju od kardiovaskularnih bolesti i hipertenzije trebaju biti oprezni s konzumacijom suhe šunke ili pršuta. Suhe šunke i pršuti su i dobar izvor mineralnih tvari, naročito cinka, željeza i selena kao i vitamina, osobito onih iz skupine B, a zbog visokog sadržaja hranjivih tvari u lako probavljivom i slobodnom obliku, naročito su pogodni u prehrani sportaša.

\section{LITERATURA}

Armero, E., J. A. Barbosa, F. Toldra, H. Baselga, M. Pla (1999): Effects of the terminal sir type and seks on pork muscle cathepsin $(B, B+L$, and $H)$, cystine proteose inhibitors and lipolytic enzyme activities. Meat Science 51, 185189.

Claeyes, E., S. De Smet, D. Demeyer, C, Geers, N. Buys (2001): Effect of rate of $\mathrm{pH}$ decline on muscle enzyme activities in two pig lines. Meat Science 57, 207-263.

Fernández, M., H. A. Ordonez, I. Cambero, C. Santos, C. Pin, L. De La Hoz (2007): Fatty acid compositions of selected varieties of Spanish dry ham related to their nutritional implications. Food Chemistry 101, 107-112.

Garcia-Gonzáles, D. L., R. Aparicio, R. Aparicio-Ruiz (2013): Volatile and Amino Acid Profiling of Dry Cured Hams from Different Swine Breeds and Processing Methods. Molecules 18, 3927-3947.

Gandemer, G. (2009): Dry cured ham quality as related to lipid quality of raw material and lipid changes during processing: Areview Grasas y Aceites 60, 297-307.

Hernández, A., L, Zomeno, B. Arino, A. Blasco (2004): Antioxidans, lipolytic and proteolytic enzyme activites in pork meat from different genotypes. Meat Science 66, 525529.

Jiménez-Colmenero, F., I. Ventanas, F. Toldrá (2010): Nutritional composition of dry-cured ham and its roll in a healthy diet. Meat Science 84, 585-593.

Jurado, A., C. Garcia, M. L. Timon, A. I. Carrapiso (2008.): Improvement of dry-cured Iberian ham sensory characteristics trongh the use of a concentrate high in oleic acid for pig feeding. Irish Journal of agricultural and food research 47, 2, 195-203.

Karolyi, D. (2002): Kakvoća buta švedskog landrasa u tehnologiji istarskoga pršuta. Magistarski rad. Agronomski fakultet u Zagrebu, Zagreb.

Karolyi, D. (2006): Chemical properties and quality of
Istrian dry-cured ham. Meso 4, 224-228.

Kos, I. (2011): Fizikalno-kemijska i senzorna svojstva dalmatinskoga pršuta različitih genotipova svinja. Doktorski rad. Agronomski fakultet u Zagrebu, Zagreb.

Kovačević, D. (2017): Kemija i tehnologija šunki i pršuta. Prehrambeno tehnološki fakultet u Osijeku. Osijek (u tisku).

Larrea, V., I. Pérez Manuera, I Hernando, A. Oniles, M. A. Lench (2007): Chemical and structural changes in lipids during the ripening of Teruel dry-cured ham. Food Chemistry 102, 494-503.

Martin, L., T. Antequera, I. Ventanas, R. Benitez-Donoso, J. J. Cordoba (2001): Free amino acids and other non-volatile componnds formed during processing of Iberian ham. Meat Science 59, 363-268.

Pleadin, I., N. Vahčić, G. Krešić, M. Malenica Staver, T. Bogdanović, T. Lešić, I. Rasponić, D. Kovačević (2015):Sezonske varijacije u sastavu masnih kiselina Istarskog i Dalmatinskog pršuta. Meso 17, 5, 428-434.

Rosell, C. M., F. Toldrá (1998): Comparison of muscle proteolytic and lipolytic enzyme levels in row hams from Iberian and White pigs. Journal of the Science of Food and Agriculture 76, 117-122.

Schivazappaa, C., M. Degnib, L. Nanni Costac, I. Russoc, L. Buttazzonid, R. Virgilli (2002): Analisis of raw meat to product proteolysis in Parma ham. Meat Science 60, 7783.

Senčić, Đ., D. Samac, A. Matić (2015): Utjecaj tjelesne mase crnih slavonskih svinja na kvalitetu slavonskih šunki. Meso 4, 324-329.

Strata A. (1993): The Parma ham in 1993: Bromatologie contents and nutritional aspects. Consortio des Prosciutto di Parma, 154.

Toldrá, F. (2006): Dry-cured ham. In:Hmi, Y. H. (Ed.) Handbook of food Science, technology and engineering, CRC Press USA, 164-168.

Toldrá, F., M. Flores (1998): The role of muscle proteases and lipases in flavor development during the processing of dry-cured ham. Critical Reviews in Food Science and Nutrition 38, 331-352.

Toldrá, F., M. Flores, M. C. Aristoy, R. Virgili, G, Parolari (1996): Pattern of muscle proteolytic and lipolytic enzymes from light and heavy pigs. Journal of the Science of Food and Agriculture 71, 124-128.

Virgili, R., G. Parolai, C. Soresi, Bordoni, G. Schivazappa (1999): Free Amino Acids and Dipeptides in Dry-cured Hams. J. Muscle Foods 10, 119-130.

WHO (2003): Diet nutrition and prevention of chronic diseases. Report of a joint WHO/FAO Expert Consultations. WHO Technical Report Series 916, Geneve.

Dostavljeno: 19.2.2018.

Prihvaćeno: 1.3.2018. 


\section{Nutritional value of dry ham and proseiutto}

\section{SUMMARY}

Due to the high content of table salt and cholesterol, as well as smoke compounds, dry-cured meat products are considered a type of food which is bad for human health because it contributes to the development of atherosclerosis and hypertension. However, dry ham and prosciutto are considered foods of animal origin for human consumption that are rich in nutrients. They represent an important source of protein and fat, which are partially disintegrated by the action of endogenous enzymes protease and lipase. They are an especially rich source of free amino acids (essential and non-essential) and fatty acids. The composition of free amino acids depends on the genotype of the pig (enzymatic composition of muscles), the processing technology and the length of curing of dry ham and prosciutto. The composition of free fatty acids mainly depends on the method of pig feeding (feed formulation) and pig rearing (open, closed), as well as on the genotype of pigs. The ratio between polyunsaturated (PUFA) and saturated (SFA) fatty acids in dry ham and prosciutto is usually below the recommended values (0.4-1), while the ratio between total $n-6$ and $n-3$ fatty acids is often above the WHO recommended values (2003). People suffering from cardiovascular diseases and hypertension need be careful when incorporating dry ham and prosciutto into their diet due to the high content of table salt (sodium). Dry ham and prosciutto are a good source of minerals, especially zinc, iron and selenium, as well as vitamins, especially B-group vitamins. Due to the high content of nutrients in easily digestible and free form, dry ham and prosciutto are particularly suitable for athletes.

Key words: dry ham, prosciutto, nutritional value

\section{Nährwert von Trockenschinken und lufitgetrockneten Rohschinken (Pršut)}

\section{ZUSAMMENFASSUNG}

Aufgrund des hohen Gehalts an Speisesalz und Cholesterin sowie Rauchbestandteilen galten getrocknete Fleischprodukte als Nahrungsmittel, die sich auf die menschliche Gesundheit ungünstig auswirken, weil sie zur Entstehung von Arteriosklerose und hohem Blutdruck beitragen. Trockenschinken und lufgetrocknete Rohschinken sind aber Lebensmittel tierischen Ursprungs, die reich an Nährstoffen sind. Sie stellen eine wertvolle Quelle von Proteinen und Fetten dar, die infolge der Wirkung von endogenen Proteasen und Lipasen teilweise abgebaut werden. Sie stellen eine besonders wertvolle Quelle von freien Aminosäuren (essentiellen und nicht essentiellen) und Fettsäuren dar. Die Zusammensetzung der freien Aminosäuren hängt vom Genotyp der Schweine ab (enzymatische Muskelzusammensetzung), der Technologie der Verarbeitung und der Dauer der Reifung von Trockenschinken und luftgetrockneten Rohschinken. Die Zusammensetzung der freien Fettsäuren hängt größtenteils von der Fütterung der Schweine (Futterzusammensetzung), dem Halterungssystem der Schweine (offen, geschlossen), aber auch vom Genotyp der Schweine ab. Das Verhältnis zwischen den mehrfach ungesättigten Fettsäuren (PUFA) und den gesättigten (SFA) Fettsäuren unterschreitet am häufigsten die empfohlenen Grenzwerte (0,4-1), während das Verhältnis zwischen dem Gesamtanteil von n-6 und n-3 Fettsäuren die empfohlenen Werte der WHO übersteigt (2003). Infolge des hohen Anteils an Speisesalz (Natrium) müssen Menschen, die an Herzgefäßkrankheiten und Bluthochdruck leiden, beim Verzehr von Trockenschinken und luftgetrocknetem Rohschinken aufmerksam sein. Trockenschinken und luftgetrocknete Rohschinken sind einer wertvolle Quelle von Mineralstoffen, in erster Linie von Zink, Eisen und Selen sowie von Vitaminen, insbesondere aus der B-Gruppe der Vitamine. Wegen des hohen Anteils an Nährstoffen in leicht verdaulicher und freier Form eignen sich Trockenschinken und luftgetrocknete Rohschinken in erster Linie für die Ernährung von Sportlern.

Schlüsselwörter: Trockenschinken, luftgetrocknete Rohschinken, Nährwert

\section{El valor nutricional dejamones secos yjamones}

\section{RESUMEN}

Por el contenido alto de la sal común y del colesterol, junto con los contenidos del humo, los productos crudo-curados son considerados comida dañina para la salud humana porque contribuyen a la aterosclerosis y a la hipertensión. Pero los jamones secos y los jamones son alimentos de proveniencia animal en la alimentación humana, ricos en nutrientes. Son una fuente importante de proteinas y grasas, en la forma semi desintegrada por las enzimas endógenas peptidasa y lipasa. Son especialmente ricos en aminoácidos libres (esenciales y no esenciales) y en ácidos grasos. La composición de los aminoácidos libres depende del genotipo de los cerdos (composición enzimática de los músculos), de la tecnología del procesamiento y del período de la maduración de los jamones secos y de los jamones. La composición de los ácidos grasos depende principalmente de la alimentación de los cerdos (composición de la comida), del sistema de la cría (extensivo, intensivo) y también del genotipo de cerdos. La proporción entre los ácidos grasos poliinsaturados (PUFA) y ácidos grasos saturados (SFA) está generalmente debajo de los valores recomendados (0,4-1) y la proporción entre los n-6 y n-3 ácidos grasos en total está por encima de los valores recomendados por la Organización Mundial de la Salud (2003). La gente que padece de las enfermedades cardiovasculares y de la hipertensión debería tener precacuión con el jamón seco y el jamón en su alimentación por su alto contenido de la sal común (el sodio). Los jamones secos y los jamones son buena fuente de los minerales, especialmente de zinc, hiero y selenio y de los vitaminas, especialmente del grupo $B$. Por el contenido alto de los nutrientes en la forma facilmente digerible y libre, los jamones secos y los jamones son particularmente adecuados para la alimentación de los deportistas.

Palabras claves: jamones secos, jamones, valor nutricional 


\title{
Valore nutrizionale dei prosciutti cotti essiceati e dei prosciutti crudi
}

\begin{abstract}
RIASSUNTO
Per l'alto contenuto di sale da cucina e di colesterolo e per l'utilizzo del fumo, i prodotti insaccati sono ritenuti alimenti nocivi per la salute dell'uomo perché favoriscono l'insorgere dell'arteriosclerosi e dellipertensione. I prosciutti cotti essiccati e i prosciutti crudi, tuttavia, sono alimenti d'origine animale ricchi di sostanze nutritive per l'uomo. Sono una importante fonte di proteine e grassi in forma parzialmente disgregata grazie all'azione degli enzimi endogeni della proteasi (o peptidasi) e della lipasi. Questi insaccati sono particolarmente ricchi di aminoacidi liberi (essenziali e non) e di acidi grassi. La composizione degli aminoacidi liberi dipende dal genotipo del suino (composizione enzimatica dei muscoli), dalla tecnologia di lavorazione delle carni e dalla durata della stagionatura dei prosciutti cotti e dei prosciutti crudi. La composizione degli aminoacidi liberi dipende soprattutto dall'alimentazione del suino (composizione del mangime), dal sistema d'allevamento del suino (a ciclo aperto, a ciclo chiuso) e anche dal genotipo del suino. II rapporto tra acidi grassi polinsaturi (PUFA) e saturi (SFA) è molto spesso sotto i valori raccomandati $(0,4-1)$, mentre il rapporto tra gli acidi grassi n-6 totali e gli acidi grassi n-3 totali supera i valori raccomandati dall'Organizzazione mondiale della sanità (OMS/WHO) nel 2003. Per la forte presenza di sale da cucina (sodio) tanto nel prosciutto cotto essiccato, quanto nel prosciutto crudo, alle persone che soffrono di malattie cardiovascolari e d'ipertensione si raccomanda di farne un uso moderato. 1 prosciutti cotti essiccati e i prosciutti crudi sono una buona fonte di sostanze minerali, in particolare di zinco, ferro e selenio, come anche di vitamine, in particolare di quelle del gruppo B. Grazie all'alta percentuale di sostanze nutritive in forma facilmente digeribile e libera, i prosciutti cotti essiccati e i prosciutti crudi sono particolarmente indicati per l'alimentazione degli sportivi.

Parole chiave: prosciutti cotti essiccati, prosciutti crudi, valore nutrizionale
\end{abstract}

\section{Konferencija o sigurnosti i kvaliteti hrane $\mathrm{RH}$}

- Vrijeme održavanja: 07.05.2018. - 09.05.2018. I

- Rok prijave: 07.05.2018.

U organizaciji Sektora za poljoprivredu, prehrambenu industriju i šumarstvo HGK u Opatiji će se od 7. do 9. svibnja održati XII. Konferencija o sigurnosti i kvaliteti hrane $\mathrm{RH}$. Molimo vas da pribilježite ove datume $u$ svom poslovnom kalendaru.

Kao i svih ovih godina, želja nam je da ovaj skup ide ukorak s vremenom i svojim temama, predavačima te načinom rada, što više odgovara aktualnim potrebama hrvatske prehrambene industrije. Stoga pozivamo sve članice HGK iz sektora prehrambene industrije i industrije pića da nam pošaljete svoje prijedloge ili ideje o temama koje biste željeli da budu obrađene na ovogodišnjoj Konferenciji i o predavačima za koje biste voljeli da svoje iskustvo i znanje podijele s vama.

https://hgk.hr/s-poljoprivredu-prehrambenuindustriju-i-sumarstvo/xii-konferencija-osigurnosti-i-kvaliteti-hrane-rh-prva-obavijest

\section{Konferencija o sigurnosti}

\section{i kvaliteti hrane RH}

\section{Opatija, 7. - 9. svibnja 2018.}

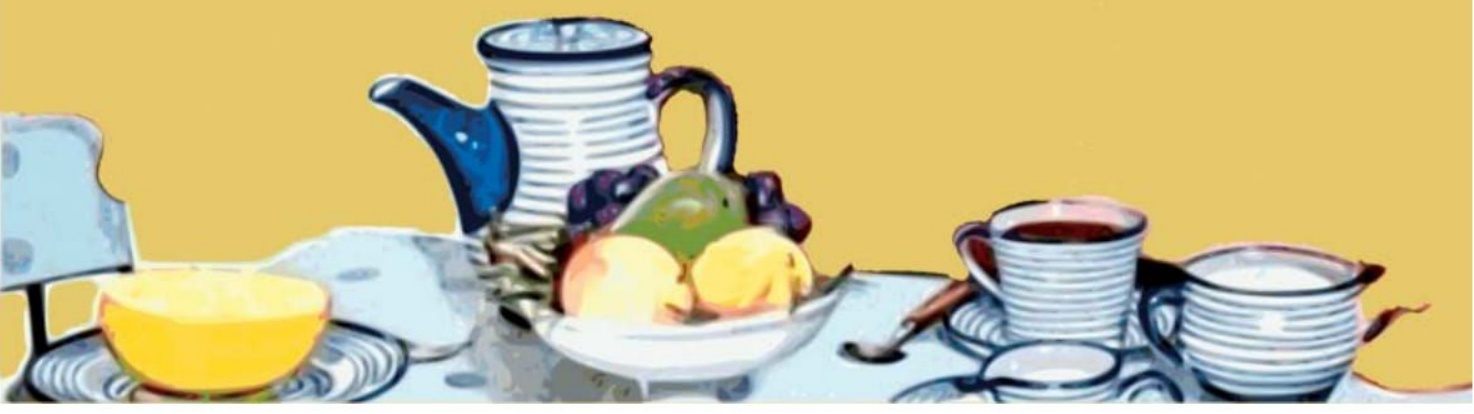

